\author{
WITOLD STARNAWSKI \\ Uniwersytet Kardynała Stefana Wyszyńskiego \\ $w$ Warszawie
}

\title{
DOŚWIADCZENIE POZYTYWNE W WYCHOWANIU MORALNYM
}

Artykuł stanowi nawiązanie do tekstu Dietricha Bennera na temat doświadczenia negatywnego i etyki eksperymentalnej. Podstawową kwestią jest możliwość (konieczność) dopełnienia negatywnego doświadczenia przez czynnik pozytywny. Problem ten ilustrują opinie Sokratesa (na temat bycia nauczycielem oraz znaczenia daimoniona), interpretacja imperatywu kategorycznego Kanta, a zwłaszcza - idei praktycznych Herbarta. Element pozytywny zdaje się być podstawą czy „horyzontem” doświadczenia negatywnego, to zaś jest „pożyteczne” dla moralnego wychowania: pokazuje bowiem wyraźną granicę między dobrem i złem i ujawnia ich obiektywność, a zarazem pomaga osobie przezwyciężyć jej słabości, egoistyczne skłonności i zakłamanie. Prawdziwa droga doskonalenia wymaga jednak pozytywnych wzorów osobowych, które można naśladować.

\section{Słowa kluczowe}

Osoba, wychowanie, etyka, negatywne doświadczenie, pozytywne doświadczenie.

Sprawa wychowania moralnego zdaje się być kluczowa, tak z perspektywy wychowania, jak i moralności; te dwie dziedziny nie są na tyle odrębne, aby można pominąć występujące między nimi związki. Nie sposób określić, czym jest sposób oddziaływania prowadzący do 
formowania osobowości i kształcenia charakteru bez uwzględnienia czynnika moralnego, z kolei wychowanie wydaje się być naturalnym przygotowaniem i dopełnieniem moralności, jej praktycznym wyrazem, realizującym się wobec innych ludzi, w społecznym środowisku. Jest to zarazem temat trudny, gdyż opiera się na nie dającym się wyraźnie uchwycić fenomenie moralności, jak i niewdzięczny - niechętnie dziś w pedagogice przywołuje się moralność.

Rozważane w tej perspektywie poglądy Dietricha Bennera zawarte w jego artykule Przekaz moralności przez doświadczenie negatywne i etyka eksperymentalna jako adekwatne formy współczesnego wychowania moralnego ${ }^{1}$ są, ze względu na autorytet Autora, ważnym także dla polskiego środowiska naukowego głosem w dyskusji nad obecnością wartości moralnych w teorii pedagogicznej. Zwłaszcza, że jest to stanowisko wyrażone językiem czytelnym dla tych, którzy odwołują się do nowoczesnych ujęć w pedagogice, jak i dla tych, którzy reprezentują bardziej tradycyjne podejście. Dwa kluczowe i powiązane ze sobą pojęcia artykułu: „doświadczenie negatywne” (negative Erfahrung) i „etyka eksperymentalna” (experimentelle Ethik) służą prezentacji propozycji kształtowania moralnego lepiej wpisującej się w doświadczenie współczesnego człowieka (będącego „w drodze”) i dostosowanej do warunków życia w społeczeństwie pluralistycznym.

Celem niniejszych uwag, nawiązujących do wspomnianego tekstu jak również do tradycyjnych ujęć wychowania (pedagogii), jest próba spojrzenia na te dwa kluczowe pojęcia („doświadczenie negatywne” i „etyka eksperymentalna”) z szeroko rozumianej perspektywy personalistycznej2. Chciałbym postawić dwa pytania: 1) czy przedstawione

1 Tytuł niemiecki: Negative Moralisierung und experimentelle Ethik als zeitgemäße Formen der Moralerziehung. Odwołuję się do wersji ogłoszonej w języku polskim [w:] D. Benner, Edukacja jako kształcenie i ksztaltowanie, wyb. i thum. z jęz. niem. D. Stępkowski, Wydawnictwo Uniwersytetu Kardynała Stefana Wyszyńskiego, Warszawa 2008, s. 29-60. Zob. tamże uwagi bibliograficzne dotyczące publikowanych wersji tekstu (numery stron odnoszące się do tego artykułu podaję w tekście, w nawiasach).

2 Chodzi o interpretację w świetle tego nurtu klasycznej myśli filozoficznej, który, odwołując się do myśli Ojców Kościoła i średniowiecznego dziedzictwa scholastycznego (Tomasza z Akwinu, Bonawentury, Dunsa Szkota), reprezentowany współcześnie 
przez D. Bennera ujęcie może zostać dopełnione „przekazem pozytywnym", nieco inaczej rozumianym niż ten, o którym mowa jest we wspomnianym artykule?; 2) jak w tym kontekście należy rozumieć „negatywność" i ,eksperymentalność” etyki i jaka jest ich efektywność w wychowaniu?

Punktem wyjścia tekstu D. Bennera jest nawiązanie do doświadczeń austriackiej pisarki Christinne Nöstlinger (swoją edukację moralną rozpoczęła ona od akceptacji kłamstwa i kradzieży) i pojawiającego się po lekturze jej powieści pytania: na czym polega kształcące obchodzenie się z wielością wzorców moralności przedstawianych człowiekowi przez „osoby znaczące” i społeczeństwo? Autor analizuje pozytywne i negatywne doświadczenia moralne $\mathrm{i}$ ich znaczenie dla wychowania moralnego w greckiej paidei, u Jana Jakuba Rousseau, w myśli I. Kanta, G. W. F. Hegla, F. Schleiermachera, wreszcie Lawrence'a Kohlberga i Fritza Osera; własną propozycję przedstawia, nawiązując do filozofii praktycznej Jana Fryderyka Herbarta. Wśród sformułowanych przez niego wniosków najważniejsze zdają się tezy dotyczące zadań wychowania moralnego. Nie ma ono prowadzić do pozytywnej moralności ani do ukształtowania cnoty dzieci i dorastającej młodzieży (cnota powstaje bowiem w późniejszym wieku jako skutek świadomej pracy nad sobą). Zadanie to polega natomiast na uświadomieniu, które $\mathrm{z}$ działań są niemoralne, jak i na ogólnym uwrażliwieniu na kwestie moralne; jest ono realizowane w dwojaki sposób: 1) powinno się „unikać doprowadzenia u uczących się do przedwczesnego skostnienia poglądów” oraz 2) należy ,ukierunkować rozwój dzieci i młodzieży na ideę etyki eksperymentalnej” (s. 60).

\section{DOŚWIADCZENIE NEGATYWNE}

Jak należy rozumieć obydwa postulaty? Autor, sięgając do myśli Platona i Arystotelesa zwraca uwagę, że w antycznej paidei wychowanie traktowane było służebnie wobec polis, chodziło o wprowadzenie

przez Étienne’a Gilsona, Jacquesa Maritaina, Karola Wojtyłę, ale także Gabriela Marcela, wskazuje na osobę jako najdoskonalszą postać bytu. 
dorastającego pokolenia w zastane obyczaje. Natomiast studiowanie zasad etycznych, a tym samym kształtowanie cnót i charakteru, przeznaczone było dla osób dorosłych. Ważne znaczenie w rozpatrywaniu kwestii negatywnego doświadczenia ma postać Sokratesa, który nie chciał występować wobec nikogo jako nauczyciel, a rozbudzenie samoświadomości moralnej widział na drodze negatywnej: poprzez krytykę, ironię, podkreślanie znaczenia nie-wiedzy. Ujawniając działanie wewnętrznego głosu - daimoniona - mówił, że ten zawsze mu coś odradza, nigdy zaś nie doradza, co ma robić. Zdaniem D. Bennera, od czasów nowożytnych „nie da się już wychowania i kształcenia ukierunkować zgodnie z jedną Ideą Dobra" (s. 36). Autor przytacza pogląd J.J. Rousseau, który opisuje wychowanie ,jako proces nie posiadający z góry wyznaczonego pozytywnego celu-kresu" (s. 37). Człowiek może już projektować swoje indywidualne życie (nie będąc podporządkowany polis, jak w starożytności), winien być wychowywany do używania swojej wolności, ale nie przez przyzwyczajenie do obyczaju lub pouczenia moralne. Wychowanie nie ma więc prowadzić do przystosowania do systemu faktycznie realizowanej moralności (obowiązujących zasad społecznego postępowania). W pierwszym okresie ma ono charakter negatywny, aby potem dorastający mogli poddawać próbie istniejące systemy moralności, wybierając takie umiejętności i działania, które „stymulują współczucie" i nie prowadzą do instrumentalnego traktowania losu bliźnich. Autor, przywołując Kanta, zwraca uwagę na znaczenie imperatywu kategorycznego w kształtowaniu samodzielności i niezależności jako istotnych cech nowożytnego wychowania. Nawiązując do Kantowskiego pojęcia oświecenia, stwierdza: „obowiązkiem dorosłych jest oświecenie samych siebie i wychowanie dorastających w taki sposób, aby rozwinęli w sobie odwagę i zdolność do bycia niezależnym od pomocy ze strony wychowawców i nauczycieli, oraz do samodzielnego myślenia i sądzenia" (s. 42-43).

W koncepcji Schleiermachera wychowanie, które zmierzać winno do tego, by człowiek zdolny był do wykształcenia w sobie indywidualności i do uczestniczenia w społeczności, ma charakter ochraniający, przeciwdziałający lub wspierający. Dwie pierwsze formy mają postać 
negatywną, wspieranie zaś ma służyć „motywowaniu do aktywnego współdziałania”. Wszystkie zaś stanowią realizację „wolności wyboru własnej formy życiowej” (s. 45) i osobistej moralności. Ta ostatnia nie jest dowolna, powinna być wyznaczona przez szacunek dla wolności drugiego człowieka, a w konsekwencji prowadzić do „współdziałania w tworzeniu i interpretacji moralności" (s. 46). Autor zwraca uwagę na negatywne rozumienie moralności w koncepcji F. Osera: jest ona przeciwieństwem zła, a zło - jak twierdzi Oser - jest „Zwierciadlanym odbiciem dobra" (s. 49). Rozwój moralny polega zatem na zmaganiu się z negatywną moralnością i doświadczeniem zła - ich konstruktywne znaczenie polega na tym, że wskazują granice zachowań niedopuszczalnych, tak w dziedzinie prywatnej, jak i publicznej.

Doświadczanie moralności (w negatywnym znaczeniu) oraz możliwość międzyludzkiej komunikacji w tym zakresie umożliwiają to, co określone jest $\mathrm{w}$ artykule jako „eksperymentalna podstawa moralności”. Droga do „interaktywnego budowania kompromisu” prowadzi przez myśl Herbarta, który daje praktyczną interpretację Kantowskiego imperatywu kategorycznego. Chodzi o sformułowane przez Herbarta idee praktyczne: wolności wewnętrznej, doskonałości, życzliwości, prawa oraz słuszności. Idea wolności wewnętrznej zawiera postulat postępowania nie za żądzami, lecz za sądem wydanym przez podmiot o własnych dążeniach; idea doskonałości - dopuszczenie wielu pragnień i nie kierowanie się ich siłą; idea życzliwości - okazywanie bezinteresownej życzliwości obcemu Ty; idea prawa - powstrzymanie swojej woli w sytuacji sporu i dopuszczenie do głosu woli drugiego. Idea słuszności potrzebna jest wtedy, kiedy dotychczasowe reguły okazują się nieadekwatne, gdyż zostały w pewien sposób naruszone i konieczna staje się ich zmiana i przeniesienie na nowy poziom. Może to nastąpić np. w sytuacji krzywdy - wówczas nie należy zgadzać się na aktywność krzywdziciela ani na pasywność krzywdzonego. Zachodzi to również w sytuacji obdarowania - wówczas również w pewnym sensie naruszona zostaje zasada sprawiedliwości i dlatego sytuacja ta powinna być zinterpretowana przez nowe reguły, które nie ustanawiałyby zależności między darczyńcą a obdarowanym. 
Elementarne sądy moralne pokazują to, czego należy zaniechać, nie wskazują natomiast tego, co należy chcieć i czynić. Przytoczmy konkluzję, w której zawarta jest wyższość subiektywnej wolności wewnętrznej, jak i moralności negatywnej: „Cenzura, jaką spełnia subiektywny charakter nad obiektywnym, nie służy przeforsowaniu jakiejś określonej pozytywnej moralności, lecz postępuje za zasadami negatywnej moralności. Nie domaga się ona, by znano dobro w jego substancjalnym sensie, lecz skupia się na tym, aby w horyzoncie motywacyjnym tropić zło, które poznano" (s. 57).

\section{MOŻLIWOŚĆ INTERPRETACJI DOPEŁNIAJĄCEJ - DOŚWIADCZENIE POZYTYWNE}

Niewątpliwie doświadczenie negatywne ma swoją wartość tak w wychowaniu, jak i w moralności, wyznacza ono granice zachowań, które jesteśmy skłonni akceptować jako dopuszczalne i „ludzkie”. Czy jednak jest ono wystarczające dla osiągnięcia właściwych celów wychowania? A ponadto, czy jest ono możliwe bez doświadczenia pozytywnego lub przynajmniej bez przyjęcia pozytywnych implikacji, które sprawiają, że określamy jakieś doświadczenie - relacyjnie - jako „negatywne”? Osobną kwestią jest wskazanie znaczenia (a wcześniej możliwości) doświadczenia pozytywnego dla pełnego rozwoju moralnego i osobowego - tą sprawą zajmę się w następnym punkcie. Obecnie chciałbym przeanalizować pojęcia „negatywnego doświadczenia moralnego” i „etyki eksperymentalnej", zwracając uwagę na to, w jakiej mierze mogą (a może muszą?) być dopełnione interpretacją odwołującą się do pozytywnego doświadczenia moralnego oraz w jakim znaczeniu „etykę eksperymentalną” można by określić jako „doświadczalną”. Przyjrzyjmy się raz jeszcze przywołanym w artykule przykładom, rozważając je w celu rozjaśnienia kwestii merytorycznych, nie historycznych. Najpierw wieloznaczny i trudny do interpretacji termin paideia. Kiedy zajmiemy się nie tym, jak starożytni Grecy rozumieli ów termin (co w dużej mierze wydaje się niewykonalne), lecz postaramy się odczytać obiektywne znaczenie tej idei, zwracając uwagę na to, jakie działania, projekty, in- 
stytucje związane były z jej realizacją, wówczas możemy ocenić, w jakiej mierze jest ona odkrywcza i wypełnia to, co dziś skłonni jesteśmy określać jako wychowanie.

Można uznać, że antyczna paideia przypisywała wychowaniu dzieci i młodzieży funkcję służebną, wydaje się jednak, że wówczas termin „wychowanie" występuje w znaczeniu zredukowanym i odpowiada on temu, co współcześnie określa się jako uspołecznianie (socjalizację). Taki aspekt wychowania (służebny wobec polis) można odnaleźć w tekstach Platona czy Arystotelesa. Także i dzisiaj można wskazać systemy wychowawcze (postulowane w teorii lub realizowane w praktyce), które podporządkowują zasady wychowawcze priorytetom ustanawianym przez władzę państwową. Pojawia się jednak pytanie, czy taka instrumentalizacja (a także ideologizacja) jest właściwą realizacją idei wychowania $^{3}$ ? Jeszcze ważniejsze jest pytanie, czy jest ona do końca możliwa? Można zakładać i sądzić, że wychowanie dzieci i młodzieży ogranicza się do wprowadzenia ich (w zachowawczym znaczeniu) do życia społecznego, lecz nie znaczy to, iż rzeczywiście może się to dokonać jedynie przez zewnętrzne kierowanie, nakłanianie i przymuszanie bez jednoczesnego (samo)formowania. I dotyczy to zarówno młodego człowieka żyjącego dziś, jak i dwa i pół tysiąca lat temu ${ }^{4}$. Kwestii tej towarzyszy pytanie: czy i w jakiej mierze jest to możliwe na drodze negatywnej?

Poważnym argumentem na rzecz ,negatywnej drogi” jest stanowisko Sokratesa, zarówno w sprawie nauczania, jak i wewnętrznego głosu daimoniona. To prawda, że on sam nie nazywał siebie nauczycielem, nie zmienia to jednak faktu, że był nauczycielem, tak dla tych, z który-

\footnotetext{
3 Jeśli zinterpretujemy platońską Ideę Dobra jako zasadę wyznaczającą realizację „idealnego porządku społecznego" i postulującą rygorystyczne ramy dla wychowania, to możemy wkroczyć na drogę rozwiązań totalitarnych i na to niebezpieczeństwo wskazywało wielu interpretatorów Platona. W określeniu „idea wychowania” chodzi o istotę i wzór, a nie o ideę w Platońskim znaczeniu.

${ }^{4}$ Gdybyśmy chcieli twierdzić, że starożytni Grecy, nie w pełni odkrywając indywidualny rys wolności człowieka, nie mogli być z tego powodu woln i (w sensie metafizycznym, a nie społecznym), prowadziłoby to do poważnych trudności antropologicznych.
} 
mi przebywał, jak i dla wielu, którzy znali go jedynie z pism Platona. Sprawa deklaracji z Obrony Sokratesa (,Ja nie byłem nigdy niczyim nauczycielem"5) nie jest zresztą jasna, może ona równie dobrze oznaczać dystansowanie się wobec sofistów nauczających za pieniądze. Zapewne Sokratesowa ironia była na służbie wiedzy negatywnej, wykazując tym, co sądzili, że coś wiedzą, iż wiedzą niewiele lub fałszywie. On sam potrafił jednak nie tylko ganić, łajać, dręczyć, ujawniać pozorne wartości, wykazywać błędy swoim rozmówcom, lecz - czyniąc tak - zarazem namawiał ich, by troszczyli się o własne dusze. „,[T]ak szedłem i próbowałem każdego z was namawiać, żeby o żadną ze spraw swoich nie dbał prędzej, zanim dbać zacznie o siebie samego, by stał się jak najlepszym i najmądrzejszym, ani się o sprawy państwa nie troszczył, zanim o państwie samym nie pomyśli"

Zwróćmy obecnie uwagę na stanowisko Kanta i rozumienie imperatywu kategorycznego. Wydaje się, że formalizm jego filozofii załamuje się w etyce. Pierwsza wersja imperatywu kategorycznego zachowuje formalny (aprioryczny) charakter: „Postępuj tylko według takiej maksymy, dzięki której możesz zarazem chcieć, żeby stała się powszechnym prawem”7 Inaczej jest w przypadku drugiej: „Postępuj tak, byś człowieczeństwa tak w swej osobie, jako też w osobie każdego innego używał zawsze zarazem jako celu, nigdy tylko jako środka"8. Ożywcza niekonsekwencja, która zmusiła Kanta do użycia w tym miejscu pojęcia „człowieczeństwo" i „osoba”, i która zdaje się stanowić ślad źródłowej intuicji rozsadzającej ramy jego systemu, w jeszcze wyraźniejszej postaci występuje w innym sformułowaniu, stanowiącym uzasadnienie drugiej wersji imperatywu. Kant pisze: „Twierdzę oto: człowiek i w ogóle każda istota rozumna istnieje jako cel sam w sobie, nie tylko jako środek, którego by ta lub owa wola mogła używać wedle swego upodobania, lecz

5 Platon, Obrona Sokratesa, tłum. W. Witwicki, [w:] tenże, Dialogi, t. 1, Wydawnictwo Antyk, Kęty 1999, s. 572 [33a].

6 Tamże, s. 576 [36c].

7 I. Kant, Uzasadnienie metafizyki moralności, tłum. z jęz. niem. M. Wartenberg, PWN, Warszawa 1984, s. 50.

8 Tamże, s. 62. 
musi być uważany zarazem za cel zawsze" " Nie wydaje się, aby użyte tu pojęcia, w tym pojęcie wartości wewnętrznej, czyli godności mogły mieć tylko charakter formalny, a tym bardziej tylko negatywny ${ }^{10}$.

Najbardziej interesujące zbieżności i pole do pozytywnego „dopełnienia" widzę w związku z analizą sądów elementarnych Herbarta i powiązanych z nimi idei: wolności wewnętrznej, doskonałości, życzliwości, prawa i słuszności. Wolność wewnętrzna oznaczać ma relację między dążeniami a osądem polegającą na tym, że „oceniający podmiot nie powinien w swoich działaniach być posłuszny żądzom, lecz powinien postępować za sądem wydanym przez siebie samego na ich temat" (s. 52). Dotykamy tu jednego z najistotniejszych punktów antropologii: najpierw relacji intelektu do prawdy, potem problemu działania (postępowania) zgodnie z poznaną prawdą ${ }^{11}$. Niezmiernie interesujące jest to, że tę drugą relację Herbart wpisuje w kategorię wolności, wbrew interpretacjom liberalistycznym, w których moment ten określa się raczej jako zniewolenie, przymuszenie; do pewnego stopnia ma to zresztą uzasadnienie w samym fenomenie: przeciwstawiać się swoim żądzom i działać zgodnie z osądem rozumu (intelektu) jest bowiem jakąś interwencją w spontaniczność pierwotnych dążeń. Herbartowskie rozumienie wolności zbliża się w tym momencie do koncepcji, w której wolnością jest stanowienie o sobie (samostanowienie).

Drugi sąd elementarny jest konsekwencją pierwszego - wzywa on: ,ani silniejszej woli - z powodu jej siły - ani słabszej - z powodu jej słabości - nie wolno dawać pierwszeństwa” (s. 53). Temu sądowi ma odpowiadać jakościowo ujęta idea doskonałości przejawiająca się m.in. we wszechstronności i wielostronności zainteresowań. Także i w tym przypadku można by przypomnieć - nie zawsze realizowany w praktyce, to inna sprawa - postulat otwartości poznawczej. Potrzeba i wręcz

\footnotetext{
9 Tamże, s. 60-61.

10 Karol Wojtyła, nawiązując do formuły Kanta, wskazuje tę wsobną, nieinstrumentalną wartość jako konstytutywną własność osoby. Por. np. K. Wojtyła, Miłość i odpowiedzialność, TN KUL, Lublin 1982, s. 29-31.

11 W taki sposób problem ten rozważa w wielu swoich tekstach - nawiązując do myśli Wojtyły - Tadeusz Styczeń.
} 
konieczność poszerzania i pogłębiania wiedzy, zainteresowań, umiejętności wynika nie tylko $\mathrm{z}$ faktu, że poznanie jest zawsze niepełne i aspektywne, ale również i z tego, że poznawanie stanowi o samym człowieku, stymuluje jego rozwój, buduje osobowość, wiąże z innymi ludźmi. Ten, kto twierdziłby, że wie już dostatecznie wiele, że poznawać więcej i lepiej nie potrzebuje, wydawałby osąd o własnej duchowej martwocie.

Trzeci sąd wiąże się z postulatem „okazywania obcemu Ty bezinteresownej życzliwości". Także i tu można znaleźć odpowiednik w tradycyjnych ujęciach, zresztą wskazuje na to sama idea bezinteresowności - dobroci, która pragnie dla drugiego jego dobra (benevolentia) ${ }^{12}$. Nie znaczy to oczywiście, że można mówić o tożsamości ujęć. Niezwykle ważną sprawą jest status „Ty” - czy odpowiada on jakiemuś intelektualnemu ujęciu człowieczeństwa, czy jest tylko znacznikiem wskazującym na „każdego”, „kogokolwiek”, a więc na konkretnego człowieka, który stoi w zasięgu poznania i działania. Ten postulat konkretności i realizmu może być trudny do odnalezienia w ujęciach trzymających się sztywno ram filozofii wyznaczonych przez Kanta.

Idea prawa, odpowiadająca sytuacji sporu i związana z czwartym sądem refleksyjnym wyznacza ramy dialogu, nie pozornego, a więc wymagającego „zawieszenia” swojej woli oraz tymczasowego „przyjęcia” i rozważenia stanowiska drugiej strony. W tym przypadku wiele zależy od tego jak należy rozumieć „poszukiwanie i negocjowanie reguły, według której zostanie rozstrzygnięty spór”. Praktyczne rozwiązania wyznaczone są przez znalezienie odpowiedniej formuły kompromisu, wydaje się jednak, że teoretyczna reguła jest już narzucona i nie trzeba jej poszukiwać ani nie należy negocjować - jest nią miara prawdy, do której każdy z uczestników sporu może i powinien się odwoływać i zarazem wobec której powinien być gotowy zweryfikować własne stanowisko.

Ostatnia idea - słuszności - związana jest ze zmianą sytuacji, a tym samym reguł działania. Interesująca jest zwłaszcza interpretacja sytu-

\footnotetext{
12 Por. analiza życzliwości jako jednego z aspektów miłości u Wojtyły; tenże, Miłość i odpowiedzialność, dz. cyt., s. 77-78.
} 
acji obdarowania. Przywołane słowa Herbarta: „Oby darczyńcy Bóg wynagrodził, jeśli swego dzieła nie uważa on za zadośćuczynienie, jakie od początku właściwie powinien i musi on czynić, aby przez same swoje dobre czyny nie powodować niesprawiedliwego stosunku" (s. 56) - brzmią jak pochwała bezinteresowności stanowiącej istotę aktu obdarowania; dobrze współbrzmią zresztą z tym, co na jej temat sądziło wielu starożytnych i współczesnych myślicieli. Słuszne wydaje się, aby obdarowani nie czuli się wobec darczyńców niedoskonali (s. 56), gdyż znaczyłoby to, że obdarowanie jest uzależnianiem. Pod warunkiem jednak, że nie prowadzi to do zniesienia obiektywnego znaczenia faktu obdarowania, nie podważa postawy wdzięczności, a tym samym nie daje podstaw do obojętności (kiedy obdarowany marginalizuje i neutralizuje akt daru, uznając, że jest to coś, co mu się należy).

Przedstawione wyżej interpretacje stanowiska Herbarta można a z perspektywy filozofii realistycznej należy - uznać za rezultat refleksji opartej na naturalnym poznaniu dobra i zła, które zarazem ma charakter intelektualny i doświadczalny. W pewnym sensie także i Kant przyjmuje naturalne rozpoznanie moralne, choć ogranicza je do ,prostego rozumu ludzkiego". Rozum taki posiada busolę, która pozwala dobrze rozróżniać dobro i zło. „,[R]ozum z tą busola w ręku potrafi we wszystkich nadarzających się wypadkach bardzo dobrze rozróżnić, co jest dobre a co złe, co zgodne $\mathrm{z}$ obowiązkiem albo mu przeciwne, jeżeli tylko, nie ucząc go zgoła nic nowego, zwrócimy jego uwagę na własną jego zasadę, jak to czynił Sokrates; że więc nie potrzeba żadnej nauki i filozofii, żeby wiedzieć, co należy czynić, aby być uczciwym i dobrym, a nawet mądrym i cnotliwym" 13 .

Pozostawiając na boku postulat wierności zasadom Kantowskiej filozofii, można zapytać, czy „moralności eksperymentalnej” (zwłaszcza tego, co się określa jako „eksperymenty z dobrem” - Experimente mit dem Guten) nie można by uznać za sposób doświadczalnej weryfikacji - jaka postać dobra winna być urzeczywistniona w konkretnej sytuacji? Pojęcie „eksperymentu” niesie w sobie dwuznaczność, która zwłaszcza

${ }^{13}$ I. Kant, Uzasadnienie, dz. cyt., s. 26. 
w przypadku moralności mogłaby budzić kontrowersje, gdyby nie zostały określone granice jego obowiązywania. Czy chodzi tu o „zderzanie się" ogólnych zasad z praktyką życiową, a więc poszukiwanie właściwej konkretyzacji, czy o wyznaczanie postępowania (a tym samym jego zasad) według kryterium wolności? W tym drugim przypadku wkraczamy w dziedzinę, w której moralność nabiera nowego kontrowersyjnego znaczenia: możliwe staje się nie tylko subiektywne definiowanie dobra, również „przesuwanie” granicy między dobrem i złem według kryteriów wyznaczonych przez wolność. Sprawa poziomu obiektywizacji i konkretyzacji działań nieco inaczej wygląda w przypadku drogi negatywnej i pozytywnej i teraz chciałbym to rozważyć.

\section{POZYTYWNY ASPEKT JAKO PODSTAWA I „HORYZONT”}

Negatywne doświadczenie ma niewątpliwe duże znaczenie i w wychowaniu, i w moralności, równie ważne jak w praktyce jest w teorii, daje jej bowiem wyraźną miarę. Nie tyle tworzy normy, co wyznacza ich dolne granice. Doświadczenie zła moralnego i wychowawczego pokazuje w sposób wyraźny i konkretny, czego czynić nie należy (nie wolno); tym samym odsłania racje na rzecz obiektywnego charakteru moralności: zło niektórych czynów jest tak radykalne i oczywiste, że nie stwarza żadnych podstaw dla swego usprawiedliwienia. Żadne uwarunkowania, wyższe racje nie są w stanie usprawiedliwić pewnych działań, to znaczy sprawić, byśmy mogli nazwać je „dobrymi”. Są nawet kategorie czynów złych w każdych okolicznościach - jedną z nich jest zabójstwo człowieka niewinnego i bezbronnego. Ale zło jest równie obiektywne w sytuacjach mniej dramatycznych, „Zwykłego” kłamstwa, „pospolitej” nielojalności i zdrady.

Doświadczeniu zła można przypisać - z perspektywy metodologicznej i poznawczej - podwójny ,pożytek” moralny (a tym samym pedagogiczny). Po pierwsze, wskazuje i ostrzega przed tym, czego „nie wolno"; chroni zatem osobę i częściowo wyznacza jej drogę, pokazując, którędy iść nie należy. Drugi „walor” jest znacznie poważniejszy - odsłania istnienie obiektywnego kryterium: doświadczenia zła nie można 
„pomylić" z doświadczeniem dobra, zło i dobro okazują się kategoriami przeciwstawnymi, wykluczającymi się - mówimy oczywiście tylko o takich sytuacjach, w których zachodzi wyraziste doświadczenie zła (nie zawsze tak jest, ale dla logiki wywodu wystarczy przyznać, że czasami tak bywa). Może warto zwrócić uwagę, że doświadczenie zła może być „pożyteczne” nie samo w sobie (trudno byłoby znaleźć dobro w złu), lecz tylko w odniesieniu do dobra. Sprawa nie jest błaha - na jaką mogłaby z pozoru wyglądać - dotykamy bowiem jednego z najtrudniejszych problemów filozoficznych: źródeł zła i jego relacji do dobra. Czy może istnieć samo doświadczenie zła? Czy na jego horyzoncie nie musi pojawić się dobro?

Trudno przecenić znaczenie moralnych i pedagogicznych konsekwencji, do których prowadzą podjęte w tej kwestii rozstrzygnięcia - opowiadamy się za odmiennymi wizjami rzeczywistości. $Z$ jednej strony mamy do czynienia $\mathrm{z}$ różnymi wersjami stanowiska, które zło (chaos, bezład) czyni podstawowym lub równorzędnym $\mathrm{z}$ dobrem składnikiem rzeczywistości - w najwyrazistszy sposób jest ono reprezentowane we współczesnych formach gnozy (neo-gnozy). Po przeciwnej stronie znajdujemy stanowiska, w których uznaje się, że zło nie jest bytem samoistnym, w ogóle nie jest bytem, lecz jego brakiem ${ }^{14}$ - $\mathrm{i}$ takie jest stanowisko nurtu klasycznego, personalistycznego. $\mathrm{Z}$ tego punktu widzenia nie można uznawać, że moralność rodzi się z doświadczenia zła (jako jego przeciwieństwo), zło zaś jest „Zwierciadlanym odbiciem dobra”. Jan Paweł II w Pamięci i tożsamości pokazuje ważną z pedagogicznego punktu widzenia zależność wynikającą z nierównoważności płaszczyzny dobra i zła. Oto co pisze: „Zło jest zawsze brakiem jakiegoś dobra, które w danym bycie powinno się znajdować, jest niedostatkiem. Nigdy nie jest jednak całkowitą nieobecnością dobra. W jaki sposób zło wyrasta i rozwija się na zdrowym podłożu dobra, stanowi poniekąd tajemnicę. Tajemnicą jest również dobro, którego zło nie potrafiło zniszczyć, które krzewi się niejako wbrew złu, i to na tej

\footnotetext{
${ }^{14}$ Mówimy tu o złu ontycznym, zło moralne ma jakąś postać bytowości, jednak i w tym przypadku ontyczna pierwszorzędność i wyższość dobra nie ulega przekreśleniu.
} 
samej glebie"15. Jedną z ważnych konsekwencji tego stanowiska jest teza, że u podstaw każdego doświadczenia jest dobro - istnienie każdego bytu jest bowiem fundamentalnym dobrem ontycznym - choćby pojawiało się tylko „w horyzoncie”, „na marginesie”. Czy teoretyczne pierwszeństwo dobra nad złem znajduje potwierdzenie w praktyce moralnej i pedagogicznej?

Umieszczenie doświadczenia zła w centrum lub u podstaw świadomości moralnej (i pedagogicznej) rodzi poważne problemy: przezwyciężenia lęku, trwogi, gniewu, wstrętu i smutku, które są naturalną reakcją na obcowanie ze złem. Reakcja ta może mieć charakter bierny lub aktywny. W pierwszym przypadku, kiedy zło zniechęca, paraliżuje wolę, potrzebny jest dodatkowy czynnik motywujący, który zdynamizowałby do działania. Aktywną negatywną reakcją na zło jest żądza odwetu, zemsty - można powiedzieć, że ta odpowiedź złem na zło jest w jakiejś mierze naturalna. Niekiedy może być ona potrzebna i właściwa (np. słuszny gniew, wymierzenie sprawiedliwej kary), ale trudno uznać, aby była to wystarczająca i właściwa odpowiedź na zło w każdych okolicznościach. Wydaje się, że każde zło, które człowiek czyni zostawia w nim jakiś ,ślad" (mówi choćby o tym znana scholastykom zasada tzw. nieprzechodnich skutków działania). Skupianie się na złu także w sensie poznawczym - a więc poznawanie zła, doświadczanie go, przeżywanie itp. - jest czymś ryzykownym $z$ wychowawczego punktu widzenia; pamiętajmy, że poznawanie jest jakimś „obcowaniem” z przedmiotem poznania, otwieraniem się nań, przyjmowaniem go do siebie (świadomościowo). $Z$ tej perspektywy można lepiej rozumieć pedagogiczny sens reguły „zło dobrem zwyciężaj” oraz przestrogi pedagogów (mędrców), aby człowiek nie dawał nienawiści dostępu do siebie.

Doświadczenie negatywne, bardzo potrzebne w rozwoju moralnym jako czynnik dodatkowy, prowokujący, korygujący, ujawniający błędy, chroniący przed skostnieniem, fałszem i zakłamaniem, nie jest zdolne do samodzielnego „uniesienia” procesu doskonalenia człowieka. Nie wydaje się, aby można było stać się dobrym (doskonałym) tylko przez

15 Jan Paweł II, Pamięć i tożsamość, Wydawnictwo Znak, Kraków 2005, s. 11-12. 
porzucenie zła. „Być dobrym” nie jest bowiem tym samym, co „nie być złym”.

Odrębną sprawą jest w wychowaniu znaczenie pozytywnego wzoru i zasady naśladowania. Praktyka pokazuje ich potrzebę, wręcz niezbędność, czy teoretyczne argumenty za ich odrzuceniem są wystarczające? Występowanie wzorów (także autorytetów) i naśladowanie ich wydaje się w wychowaniu czymś naturalnym i sprawdzonym, i jest raczej faktem danym do wyjaśnienia niż projektem (propozycją), którą należałoby naukowo uzasadniać, aby ją „uprawomocnić” dla praktyki. Zasada naśladowania tego, co dobre (lepsze, doskonalsze) jest samozrozumiała w działalności praktycznej człowieka; pozostaje pytanie, czy jest ona również właściwa $\mathrm{w}$ działaniu moralnym, czy nie niweczy istoty moralności? Można tu postawić trzy pytania: 1) czy nie ogranicza wolności człowieka?; 2) czy nie zawęża działań do ,jedynie słusznych”, eliminując różnorodność i pluralizm?; 3) wreszcie, czy jest owocna i możliwa: doskonały wzór zdaje się niedostępny, a naśladowanie kogoś, kto jest niedoskonały, staje się kontrowersyjne.

Trudno w pełni odpowiedzieć na postawione pytania, można tylko wskazać kierunek odpowiedzi ${ }^{16}$. W sprawie wolności - jeśli nie rozumie się jej w dogmatyczny sposób niedopuszczający żadnego określenia i ograniczenia, lecz przyjmuje się, że właściwie opisuje ją kategoria stanowienia o sobie - warto zauważyć, że tak wybór osoby-wzoru, jak i drogi naśladowania jest (powinien być) aktem wolnym. Także wtedy, kiedy jest to decyzja błędna lub kiedy zostanie później zakwestionowana (zmieniona) przez człowieka. To prawda, że poddanie się wzorowi (autorytetowi) może zniweczyć autonomię osoby, może doprowadzić do służalczego czy ślepego uzależnienia, ale ustanowienie takiej relacji nie jest możliwe bez samozniewolenia, bez decyzji lub tylko biernej zgody na zniewolenie (zniszczenie autonomii własnego ,ja”) ${ }^{17}$. Osoba-

\footnotetext{
16 Przy okazji warto zauważyć, że logika doświadczenia negatywnego także zakłada rodzaj anty-wzoru i anty-naśladowania.

17 Akt religijnego „wyrzeczenia się siebie” mimo zewnętrznych podobieństw do biernego zniewolenia pozostaje wypełnieniem, a nie zaprzeczeniem wolności i dowodem na trudną już niemal do zrozumienia moc i wspaniałomyślność ,ja” władającego sobą.
} 
wzór, a zwłaszcza zasada naśladowania - jeśli tylko nie jest rozumiana jako dosłowne i naiwne powielanie czyjegoś postępowania - nie może prowadzić do jednostronności, ale wyzwala rozmaitość i pluralizm już choćby z dwu powodów: 1) ze względu na odmienność osób (nikt nie może stać się kimś innym, a jeśli za wszelką cenę chce nim zostać, staje się groteskowy); 2) z uwagi na odmienne okoliczności czasu i miejsca.

Warto zwrócić uwagę, że zasada naśladowania (w aspekcie wychowawczym lub moralnym) $\mathrm{z}$ istoty zmierza do uchwycenia pewnego podobieństwa (analogii) w aspekcie duchowym. Nie da się materialnie (dosłownie) naśladować czyjejś wytrwałości, męstwa, szlachetności, nigdy bowiem ani czyny, ani okoliczności, ani osoby nie będą takie same. Czy można powiedzieć, że wzór narzuca ,jedynie słuszne” odpowiedzi? Chyba tylko w bardzo ogólnych zarysach możemy pokazać takie ,jedynie słuszne" odpowiedzi, które zresztą są zwykle wyznaczane przez doświadczenie negatywne; to znaczy nie należy krzywdzić, lecz pomagać, mówić prawdę - nie kłamać, czynić dobro - nie zło. Działanie jest zawsze konkretne i choć ogólne zasady są pomocne i wiążące, to ani „zasady”, ani nikt z zewnątrz (tym bardziej ten, kto tylko teoretycznie rozpatruje rozmaite przypadki), nie może zastąpić konkretnego człowieka, który w swoim sumieniu rozstrzyga, decyduje i odpowiada za własne czyny. Pierwszorzędne znaczenie ma to, czy czyni to w sposób wolny i odpowiedzialny, wtórne (a nawet trzeciorzędne) - to, jak zostanie oceniony przez innych. Indywidualne czyny osób tworzą fundament pluralizmu, także wtedy, kiedy ludzie działają razem, zgodnie; różnorodność (ontyczna, osobowościowa, związana z okolicznościami) jest wystarczająco mocnym fundamentem pluralizmu i nie musi on być wytwarzany przez „sztuczne” odrębności.

Wzór zdaje się zawierać w sobie antynomię: jeśli jest realny jest niedoskonały, doskonały zaś jest nierealny ${ }^{18}$. Ta trudność pedagogii ma inne znaczenie w teorii, inne w praktyce. Trudno jest uznać istnienie doskonałych wzorców osobowych - wszechstronna doskonałość nie jest

18 Wzór-Osoba Jezusa Chrystusa jest przezwyciężeniem tej antynomii, jest bowiem i konkretny, i doskonały; na tym w gruncie rzeczy polega owocność pedagogii chrześcijańskiej. 
bowiem przymiotem człowieka, można więc mówić raczej o doskonałościach cząstkowych, niepełnych, ograniczonych do pewnych czynów, okresów życia. Wtedy, kiedy mówimy o wzorach, którymi są konkretne osoby, łatwo znaleźć przejawy niedoskonałości. Doświadczony wychowawca wie, że nie należy słabości, wad czy win osoby-wzoru ukrywać, a jej życiorysu upiększać. Odbiera się wówczas wiarygodność przekazu i naraża na katastrofalne skutki nadużycia zaufania; zanieczyszczenie przekazu fałszem sprawia, że w każdej chwili jego wartość może być podważona, a sens przekazu zniweczony. Niebezpieczeństwo idealizowania wzorów ułatwia instrumentalne ich wykorzystanie i w gruncie rzeczy utrudnia proces wychowania: osłabia oddziaływanie (to, co wyidealizowanie piękne i bez skazy częściej skłania do podziwu i emocjonalnego rozmarzenia niż do czynu), a ponadto zamazuje dynamiczny i prawdziwie osobowy rys wychowania, jakim jest zmaganie się człowieka z losem i z samym sobą.

Nie można również zapominać o groźbie ubóstwienia wzoru - przekonanie, że ktoś, kto dokonał mężnego czynu, zachował się szlachetnie, umiał stawić czoła trudnościom jest $\mathrm{i}$ w innych dziedzinach doskonały jest nieuprawnioną ekstrapolacją doskonałości. Bardzo szkodliwą wychowawczo - kiedy bowiem wady i słabości wyjdą na jaw, a prędzej czy później wyjść muszą, zwykle kwestionuje się również to, co dobre i szlachetne, zapominając, że życie jest utkane ze wzlotów i upadków i żaden człowiek nie jest wolny od pokusy ulegania własnej pysze i egoizmowi ${ }^{19}$.

Doświadczenie negatywne jest ważnym elementem wychowania dla pedagogii negatywnej, czyli tej, która wyzwala człowieka z wad i słabości; jej zadanie właściwe nigdy się nie kończy, sile złych skłonności człowiek może ulec na każdym etapie życia. Pedagogia pozytywna, której celem jest doskonalenie człowieka, budowanie i utrwalanie w nim dobra (a nie tylko odwodzenie od zła) potrzebuje doświadczenia pozytywnego, a równocześnie pomocy ze strony godnych naśladowania

\footnotetext{
19 Opis słabości Apostołów zawarty w Ewangeliach powinien być dla pedagogii
} chrześcijańskiej wymowną wskazówką. 
osób-wzorów. Jednym z takich wzorów (ale przecież nie jedynym, gdyż nie obowiązuje w tej dziedzinie zasada „wyłączności”) był Sokrates. Jeśli twierdził on, że daimonion mówił mu tylko to, czego ma nie robić, a nic mu nie nakazywał, to może i dlatego, że sprzeciw wobec konkretnego zła (które się już dokonało lub ma dokonać) jest zawsze wyrazisty i ,jedynie-słuszny”, wybór zaś dobra jest zawsze wolną i twórczą decyzją człowieka, który może je realizować „na tysiąc sposobów”. Doświadczenie zła „mówi” wyraźnie: „nie wolno ci”, „musisz”, „nie powinieneś", natomiast ,apel” o dobry czyn jest z istoty subtelniejszy i obarczony zastrzeżeniem ,jeżeli chcesz”. Doświadczenie zła wyznacza dolną i wyrazistą granicę, doświadczenie dobra nie wskazuje na żadną granicę (bo nie ma dla człowieka górnej granicy dobra) i nikt nie może powiedzieć, że uczynił w danej sytuacji wszystko dobro, a on sam jest „wystarczająco dobry”. Przed ślepotą i samozadowoleniem może go wówczas obronić doświadczenie negatywne - własnej niemocy, słabości, niedoskonałości.

\section{BIBLIOGRAFIA}

Benner D., Przekaz moralności przez doświadczenie negatywne i etyka eksperymentalna jako adekwatne formy wspótczesnego wychowania moralnego, [w:] tenże, Edukacja jako ksztatcenie i kształtowanie, wyb. i thum. z jęz. niem. D. Stępkowski, Wydawnictwo Uniwersytetu Kardynała Stefana Wyszyńskiego, Warszawa 2008, s. 29-60.

Jan Paweł II, Pamięć i tożsamość, Wydawnictwo Znak, Kraków 2005.

Kant I., Uzasadnienie metafizyki moralności, tłum. zjęz. niem. M Wartenberg, PWN, Warszawa 1984.

Platon, Obrona Sokratesa, tłum. W. Witwicki, [w:] tenże, Dialogi, t. 1, Wydawnictwo Antyk, Kęty 1999.

Wojtyła K., Miłość i odpowiedzialność, TN KUL, Lublin 1982. 


\section{POSITIVE EXPERIENCE IN MORAL UPBRINGING}

This subject refers to Dietriech Benner's article on negative experience and experimental ethics. The principal question is a possibility (or necessity) of fulfillment of a negative experience by a positive factor. This question is exemplified on Soctrates opinion (to be a teacher and meaning of daimoniom), interpretation of Kant's categorical imperative and - especially - Herbart's practical ideas. A positive element seems to be the basis or "horizon" of a negative experience. The negative one is ,useful" for moral education: it shows a clear border between good and evil and reveals objectivity of them and help a person to overcome his or her faults, egoistic inclinations and hypocrisy. But the true way of perfection requires positive personal examples, which then can be followed.

\section{Key words}

Person, upbringing, ethics, negative experience, positive experience. 